\title{
Freshwater Cyanobacterial Blooms and Cyanotoxin Production in Serbia in the Past 25 Years
}

\begin{abstract}
Zorica Svirčev', Jelica Simeunović' Gordana Subakov-Simić ${ }^{2}$, Svetislav Krstić ${ }^{3}$, Milka Vidović ${ }^{4}$
\end{abstract}

\begin{abstract}
Since 1980 cyanobacterial blooms occurred in a large number of reservoirs, lakes and water flows (rivers and channels) in Serbia. Among 83 water ecosystems examined, 58 were found in blooming condition almost every year during last 2 decades. All natural lakes, accumulations, rivers and chanals in Vojvodina province (agricultural part) proved to be sites with frequent cyanobacterial proliferation. During the summer 2005-spring 2006 microcystin-LR survey in Vojvodina, the toxin was permanently present in all examined ecosystems and the highest value of $362.68 \mathrm{\mu gL}^{-1}$ was detected in Ludoš Lake.

The part of Central Serbia is very problematic for ground water supply. For that reason more than 20 reservoirs serve as drinking water suppliers. Significant and persistant cyanobacterial blooms have been recognized in 9 of them. Samples for cyanotoxin analyses were taken during and after blooms in Ćelije Reservoir and in drinking water in Kruševac town 2 days later. Concentration of microcystin-LR was $650 \mathrm{gL}^{-1}$ in the reservoir, while the tap water contained $2.5 \mathrm{MgL}^{-1}$
\end{abstract}

Key words: Cyanobacteria, blooms, cyanotoxins, Serbia

Department of Biology and Ecology, Faculty of Sciences, University of Novi Sad, Trg Dositeja Obradovića 2, 21000 Novi Sad, Serbia

2 Institute of Botany and Botanical Garden "Jevremovac", Faculty of Biology, University of Belgrade, 11000 Beograd,Serbia

3 Institute of Biology, Faculty of Natural Sciences, 1000 Skopje, Macedonia

${ }^{4}$ Institut of Chemistry, Technology and Metallurgy, University of Belgrade, Negoševa 12, 11000 Belgrade, Serbia

\section{Introduction}

During the past decades significantly more frequent occurence of cyanobacterial "blooms" in aquatic systems has been detected and mainly attributed to global warming, increased eutrophication as well as the dispersal of cells through ship traffic (Kahru et al., 1994; Sellner et al., 2003). However, the main factors triggering or controlling cyanobacterial "blooms" have not yet been fully understood (Hense and Beckmann, 2006). In general, low concentrations of dissolved inorganic nitrogen (DIN) and a surplus of phosphorus (DIP) are considered prerequisites for enhanced growth and bloom formation of $\mathrm{N}_{2}$-fixing cyanobacteria (Kahru et al., 200o). This can explain the occurrence of cyanobacteria after the spring "bloom" of phytoplankton, when DIN is exhausted whereas DIP is still available. In addition to low DIN/DIP ratios several other factors are thought to stimulate bloom formation of cyanobacteria: warm water temperatures under calm weather conditions and the corresponding strong stratification are assumed (but not confirmed) to be necessary. Under severe nutrient depleted conditions, the ability of some cyanobacteria species to take up dissolved organic phosphorus (Huber and Hamel, 1985; Mulholland et al., 2002) and/or to control their buoyancy (Villareal and Carpenter, 2003) may lead to a distinctive advantage over phytoplankton. Other hypotheses for the success of some species include, e.g. a reduced grazing pressure (due to their harmfulness) (Hanazato, 1996; Gobler et al., 2007) or the exclusion of competition (due to shading effects by forming surface scums) (Oliver and Ganf, 2000).

Cyanobacteria are found in freshwater and the sea as well as in all terrestrial environments. They often occur in toxic water blooms and the toxins belong to various classes of substances (Codd, 1995; Chorus and Bartram, 1999). They are responsible for poisoning cases numerous of livestock and other animals, but sometimes they in- duce serious problems in humans. Beside a long list of toxins, cyanobacteria release other secondary metabolites with cytotoxic or cytostatic activity, some also with tumor promoting activity (Svirčev, 2006).

Cyanotoxins are a very diverse group of toxins. They are either membrane bound or exist free inside the cells. Release of toxins occurs during the cell life, but mostly after cell death through passive flow out of the cellular content. Very interesting point of toxic cyanobacteria is the presence of different toxins within same genus and, on the other hand, the presence of the same toxins in widely different genera. Another specificity of cyanotoxins is the very great variability in toxicity and level of toxicity even between different strains within same species (Dow and Swoboda, 200o). Cyanobacterial toxins include neurotoxic alkaloids (anatoxin-a, anatoxin a(s), saxitoxins), hepatotoxic peptides (microcystins) and the hepatotoxic alkaloid (cylindrospermopsin) (Fitzgerald, 2001).

The presence of toxic cyanobacterial blooms occurring in bodies of water used either as drinking water reservoirs or for recreational purposes may represent serious health risks for the human population. A large number of intoxications not only of cattle (Puschner et al., 1998), dogs (DeVries et al., 1993), and waterfowl (Matsunaga et al., 1999), but also of humans has been reported. The tragic deaths of 76 patients in a hemodialysis clinic in Brazil in 1996 was connected to the presence of cyanobacterial toxins in the water supply (Carmichael et al., 2001) and a high incidence of primary liver cancer in China has been attributed to drinking water contaminated with cyanobacterial toxins (Ueno et al., 1996; Harada et al., 1996).

The presence of cyanobacterial toxins in drinking water supplies poses a serious problem to water treatment facilities since not all technical procedures are able to effectively remove these toxins to below acceptable levels (Hoeger et al., 2002). Despite this, it is highly unlikely that lethal poisonings would occur following con- 
sumption of drinking water contaminated with cyanobacterial toxins. Of much higher concern are low level chronic exposures, since the risks associated with long-term exposure have not been adequately described (Fitzgerald, 2001). Current drinking water treatment practices in Serbia do not regularly monitor or actively remove these toxins from the drinking water since this is a relatively new field of study and would involve extremely expensive measures (Falconer, 1999; Heinze, 1999). Even with treatment, low level chronic exposure to the hepatotoxins, leading to tumor promotion or even carcinogenesis is possible in persons consuming drinking water derived from surface water treatment reservoirs.

The aim of this study was to collect existing results and data bases regarding cyanobacterial "blooms" for Serbia in the past 25 years and to present the first results on cyanotoxins analysis in water ecosystems in Serbia.

\section{Material and Methods}

\section{Study area}

Mass occurance and blooms of cyanobacteria were studied in all water bodies (rivers, chanals, lakes and accumulations) that had been examined in Serbia during the period 1980-2002.

\section{Data basis for cyanobacterial "blooms"}

Mass occurence and "blooming" of potentially toxic cyanobacteria is analysed via informations from relevant data bases (Hydrometeorological Institute of Serbia; Department of Biology and Ecology, Novi Sad; Faculty of Biology, Belgrade; Biology Department, Kragujevac; "Srbija Vode", Belgrade; "Vojvodina Vode", Novi Sad; Institute for Nature Protection, NoviSad) and published references (Blaženčić et al.,1990; Branković, 1992; Branković et al., 1998; Grašić et al., 2004; Čađo et al., 2003; Čađo et al., 2004a,b; Čomić and Ranković, 1991; Dulić and Mrkić, 1998, 1999, 2001; Đukić, 1991a,b,c,d; Đukić et al.,1994; Đurković et al., 2004; Kalafatić et al., 1982; Karadžić and Subakov-Simić, 2002; Karadžić et al., 2005, 2006; Laušević et al., 1998; Marković and Svirčev, 1998; Martinović-Vitanović and Kalafatić 1990, 1996; Maslać et al., 1992; Milovanović 1963, 1970; 1973; Milovanović and Živković, 1953,1959, 1963; Miljković et al. 2004; Obušković, 1982a,b, 1983, 1986, 1987, 1989, 1991; Obušković and Kalafatić, 1988; Peršić, 1997; Pujin and Ratajac, 1990; Pujin et al., 1986, 1987, 1999; Ranković and Čomić, 1989; Ranković et al., 1994; Ranković and Simić, 2005; Ristić et al., 1979; Seleši, 1981, 1982; Simeunović et al., 2005; Subakov-Simić, 2004; Svirčev, 1983; Urošević, 1993).
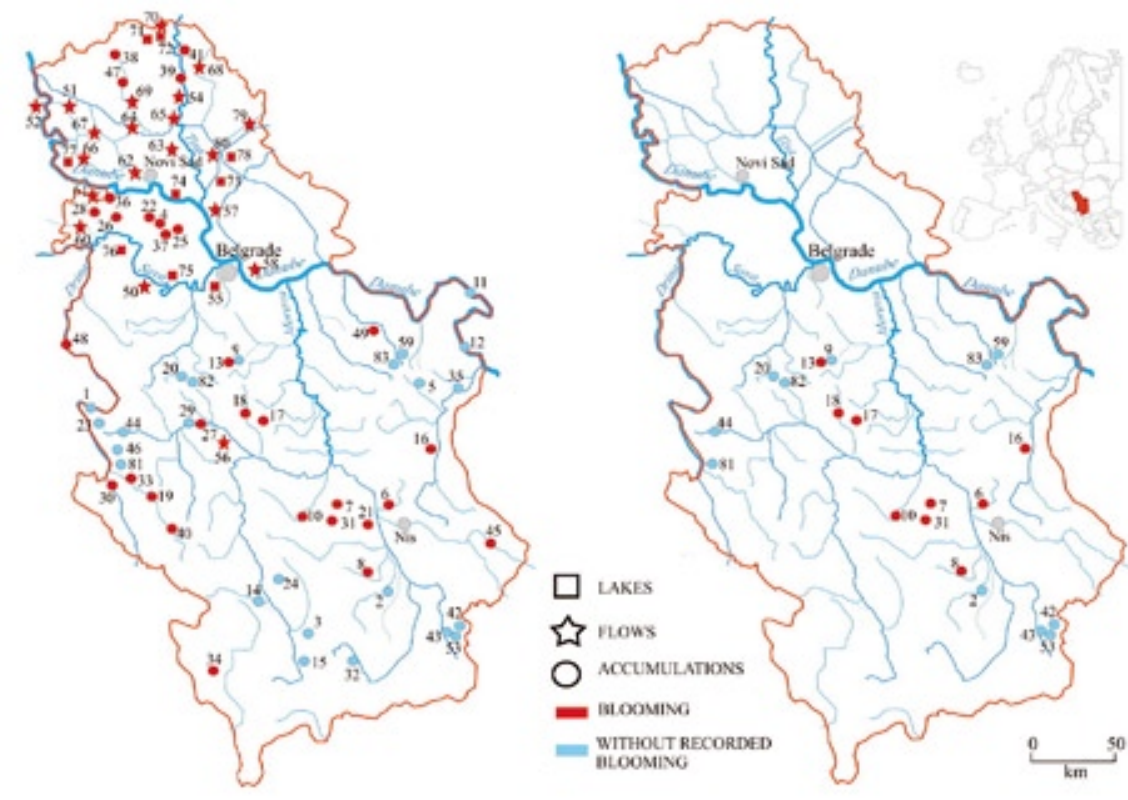

Figure 1 (A) Freshwater ecosystems monitored in the past 25 years in Serbia with detected blooming events; (B) Drinking water supply reservoirs in Central Serbia with blooming ones marked by red dots

Legend: 1.Bajina Bašta, 2.Barje, 3.Batlava, 4.Borkovac, 5.Borsko jezero, 6.Bovan, 7.Bresnica, 8.Brestovac, 9.Bukulja, 10.Ćelije, 11.Đerdap I, 12.Đerdap II, 13. Garaši, 14.Gazivode, 15.Gračanka, 16.Grlište, 17.Grošnica, 18.Gruža, 19.Kokin Brod, 20.Kamenica, 21.Krajkovac, 22.Kudoš, 23.Lazić, 24.Lisina, 25.Ljukovo, 26. Međeš, 27.Međuvršje, 28.Moharač, 29.Ovčar Banja, 30.Potpeć, 31.Pridvorica, 32.Prilepnica, 33.Radojina, 34.Radonji, 35.Sokolovica, 36.Sot, 37.Šelovrenac, 38.Tavankut, 39.Tisa, 40.Uvac, 41.Tisa-Novi Kneževac, 42.Vlasina, 43.Vrla 2, 44.Vrutci, 45.Zavoj, 46.Zlatibor, 47.Zobnatica, 48.Zvornik, 49.Pek-Blagojev kamen, 50.Sava Litije-Ostružnica, 51.Kanal Odžaci-Sombor, 52.Dunav-Apatin, 53.Vrla1, 54. Mrtva Tisa-Mol, 55.Rakina bara, 56.Zapadna MoravaČačak, 57.Opovački Dunavac, 58.Ponjavica, 59.Veliki Zaton, 60.Bosut, 61.Studva, 62.DTD-Novi Sad, 63.Jegrička, 64.DTD-Vrbas, 65.DTD-Bačko Gradište, 66.DTD-Bač, 67.DTD-Srpski Miletić, 68.Zlatica, 69.Krivaja, 70.Kereš, 71.Palić, 72.Ludoš, 73.Carska bara, 74.Koviljski rit, 75.Obedska bara, 76.Zasavica, 77.Provala, 78.Ečka, 79.Stari Begej-Srpski Itebej, 80.Tamiš-Botoš, 81.Ribnica, 82.Divčibare, 83.Pustinjac.

\section{Microcystin LR measurements}

Microcystin monitoring in various fresh water ecosystems in Vojvodina (lakes, accumulations, rivers and channels) has been performed from summer 2005 to spring 2006 on 16 different localities: Borkovac, Palić Lake, Ludoš Lake, Zobnatica, Koviljski rit, DTD (Channel Danube-TiszaDanube) -Bečej, Krivaja-Srbobran, DTDVrbas, DTD-Srpski Miletić, Tavankut, Tisa-Novi Kneževac, Tisa-Bačko Gradište, Begej-Srpski Itebej, Tamiš-Botoš, DTDBačko Gradište, by means of standard water sampling methods. Microcystin concentration was measured in only one water supply reservoir in Central Serbia (Ćelije) during the cyanobacterial bloom in July 2004.

Colorimetric protein phosphatase inhibition assay (inhibition of enzyme protein phosphatase $1-\mathrm{PP}_{1}$ ) was used for the detection of microcystin-LR concentration in water samples (An and Carmichael, 1994). Samples were concentrated by filtration through $0.45 \mu \mathrm{m}$ membrane filter and extracted with $75 \%$ methanol (Fastner et al.,1998). PP1 activity was determined by mesaurement the rate of color production from the liberation of p-nitrophenol from the substrate p-nitrophenil phosphate, measured at $405 \mathrm{~nm}$ using the microtiter plate reader. The assay was carried out at $37^{\circ} \mathrm{C}$ for 2 hours. Toxin concentrations were determined using standard inhibition curve of microcystin-LR (SIGMA).

\section{Results}

\section{Cyanobacterial "blooms" of water ecosystems in Serbia}

As far back as 1980, large number of water ecosystems in Serbia was found in "blooming” (Fig.1A). Among 83 water ecosystems examined, 58 were found in blooming condition during last 2.5 decades. All natural lakes, accumulations, rivers and chanals in Vojvodina province (agricultural part) proved to be sites with frequent cyanobacterial proliferation.

Dominant "blooming" cyanobacterial taxa belonged to Microcystis, Aphanizomenon, Anabaena and Oscillatoria (Planktothrix) genera, represented by the most frequently observed Microcystis aeruginosa, M. flos-aquae, Aphanizomenon flosaquae, Anabaena flos-aquae, A. spiroides, Planktothrix agardhii taxa, all of which are well known toxin producers.

The part of Central Serbia has been found to be very risky for surface reservoirs water supply since more than 20 reservoirs serve as drinking water suppliers, 9 of which were detected in severe and prolonged cyanobacterial "blooming" (Fig.1B). 


\section{The first results of microcystin analyses in Serbia}

Table 1 represent the very first results on cyanotoxin (microcystin) concentrations detected in water bodies of Vojvodina, Serbia. During 2005 and 2006 the presence of microcystin-LR in water samples was screened using $\mathrm{PP}_{1}$ assay with peak values in the autumn 2005 and spring 2006 at location Ludoš Lake. The concentration of microcystin-LR in the water samples were in the range of $1.25-362.68 \mu \mathrm{gL}^{-1}$. The highest concentration of microcystin-LR detected at location Ludoš Lake was 362.68 $\mu \mathrm{gL}^{-1}$ in autumn 2005 and in spring 2006 $268.07 \mu \mathrm{gL}^{-1}$. In summer 2005 and winter 2006 the highest microcystin concentrations were detected at accumulation Borkovac $\left(165.48 \mu \mathrm{gL}^{-1}\right.$ and $\left.226.06 \mu \mathrm{gL}^{-1}\right)$.

Table 1 Cyanobacterial toxins (microcystin-LR) present in water ecosystems survey in Vojvodina for summer 2005 - spring 2006 period.

\begin{tabular}{|l|l|l|l|l|}
\hline \multirow{2}{*}{ Locations } & \multicolumn{4}{l}{ Concentration of microcystin - LR $(\boldsymbol{\mu g} \mathbf{L}-\mathbf{1})$} \\
\cline { 2 - 5 } & $\mathbf{s u m m e r} \mathbf{2 0 0 5}$ & autumn 2005 & winter 2006 & spring 2006 \\
\hline Borkovac & 165.48 & 152.78 & 226.06 & 12.90 \\
\hline Palić & 40.98 & 119.43 & 9.45 & 136.68 \\
\hline Ludoš & 70.59 & 362.68 & 4.21 & 268.07 \\
\hline Zobnatica & 10.97 & 121.07 & 1.91 & 18.77 \\
\hline Koviljski rit & 85.75 & 96.32 & 1.25 & 10.06 \\
\hline DTD-Bečej & 9.73 & 65.32 & 1.48 & 16.85 \\
\hline Krivaja-Srbobran & 14.01 & 79.56 & 1.43 & 33.11 \\
\hline DTD-Vrbas & 7.99 & 10.63 & 4.24 & 9.78 \\
\hline DTD-Sr. Miletić & 4.39 & 9.01 & 1.86 & 13.23 \\
\hline Gornji Tavankut & 3.65 & 8.71 & 2.76 & 6.84 \\
\hline Tisa-N. Kneževac & 6.87 & 5.48 & 8.44 & 10.37 \\
\hline Tisa-B. Gradište & 115.36 & 25.29 & 8.37 & 122.39 \\
\hline Srpski Itebej & 9.75 & 8.74 & 1.27 & 11.92 \\
\hline Tamiš-Botoš & 7.42 & 8.84 & 1.64 & 5.03 \\
\hline DTD-B. Gradište & 104.34 & 346.85 & 2.34 & 102.74 \\
\hline
\end{tabular}

In water samples at 10 locations (Borkovac, Palić, Ludoš, Zobnatica, Koviljski rit, Krivaja-Srbobran, Tisa-B.Gradište, DTDVrbas, DTD-Bečej and DTD-B. Gradište) during 2005 and at 12 locations (Borkovac, Ludoš, Palić, Zobnatica,Tisa-B.Gradište, Tisa-N. Kneževac, Koviljski rit, DTDBečej, DTD-Sr. Miletić, Krivaja-Srbobran, Begej-Sr. Itebej and DTD-B.Gradište) during 2006, the microcystin concentration was higher than $10 \mu \mathrm{g} \mathrm{L}^{-1}$. Microcystin concentrations detected in water samples from other locations were below that value.

"Blooming" of potentially toxic cyanobacteria has also been recorded in other reservoirs, like Ćelije (Plate 1). In July 2004, Ćelije reservoir, used as drinking water supply for city of Kruševac and its surroundings, was found "blooming" with taxa belonging to Aphanizomenon, Anabaena and Microcystis. This mass development of toxic cyanobacteria resulted in concentration of microcystin LR 650 $\mu \mathrm{gL}^{-1}$ in water of the reservoir, while in the drinking (tap) water of Kruševac city the

\section{Disscussion}

\section{Cyanobacterial "blooms" in Serbia}

According to references (listed under 2.2.1.), more than 80 water ecosystems (lakes, rivers, reservoirs) in Serbia have been monitored for "water blooms" in the last 25 years. In this period, "blooms" have been observed in 58 of them, representing $70 \%$ of the total number, while all 36 monitored ecosystems in Vojvodina region have been "blooming" in different seasons. Lakes and reservoirs were mostly affect ed by "blooming" events, cyanobacterial concentration was $2.5 \mu \mathrm{gL}^{-1}$.

\section{Microcystins in Serbia}

Detected levels of microcystin in Vojvodina water ecosystems creates certain ques- tems in Vojvodina region (100\%) and in 22 Eutrophication has a significant environmental (aquatic) polan the developed countire register $54 \%$ of the lakes in Asia and $\mathrm{Pa}$ South America, while only $28 \%$ registered eutrophic lakes in Africa (Bartram et al., 19. Having nearly $70 \%$ of water ecosys25 years, the eutrophication problem might within countires with the worst surface water quality. tions that need to be elaborated a bit more in detail. Firstly, these results are more or less expected since Simeunović et al. (2005) have shown that water ecosystems in Vojvodina do often "bloom" with potentially toxic and toxic cyanobacteria. Explaining the low, but more or less constant, values of microcystin toxin is more difficult, and can be attributed generally on: i) lack of regular monitoring, ii) lack of coordinated sampling activities during and after "blooming" and iii) degradation of toxins either by bacteria (Takenaka and Watanabe, 1997), UV light (Tsuji et al., 1995) or humic substances (Welker and Steinberg, 1999). The laboratory experiments by Cousins et al. (1996) demonstrated that primary degradation of microcystin-LR in reservoir water occurred in less than one week.

Cyanotoxins can be acutely toxic to humans depending on environmental concentrations to which people might be exposed, e.g. through oral uptake. Microcystin concentrations typically range between 1 and $100 \mu \mathrm{gL}^{-1}$ in the open water during enhanced cyanobacterial growth, but concentrations up to $25 \mathrm{mgL}^{-1}$ in cell accumulations, e.g. at shorelines, have been found and may be even higher during presence of clones with higher cellular microcystin contents. Chorus and Fastner (2001) calculated that for a averagely sensitive $10 \mathrm{~kg}$ child an acutely lethal dose could be reached by ingestion of 1-2 liters of such a cyanobacterial suspension of "pea soup" consistency which contained $25 \mathrm{mgL}^{-1}$ of microcystin (at an $\mathrm{LD}_{50}$ of $5 \mathrm{mg}$ per $\mathrm{kg}$ body weight or $50 \mathrm{mg}$ for the $10 \mathrm{~kg}$ child). Acutely lethal intoxication, particularly of small children, through ingestion of scum material therefore cannot be dismissed as a possibility under circumstances of heavy scum formation with very high microcystin content in the cyanobacterial cells.

On the other hand, it is also very difficult to relate this kind of low toxin levels, although in a prolonged time period, to eventual human health risk. Controversial results in Falconer et al. (1994) test on pigs or Fawell et al. (1999) on mice, that detected only minor changes in liver cell histology and slight increase of liver enzyme values, were not conclusive for any relation to the toxin exposure and contained numerous uncertainty factors. Nevertheless, WHO expert group (Falconer et al., 1999) developed a guideline value $(\mathrm{GV})$ of 20.000 cyanobacterial cells per $\mathrm{ml}$, or 2-10 $\mu \mathrm{gL}^{-1}$ microcystin, as a health hazard value in recreational waters. According to results presented in Table 1, although collected seasonally and outside "blooming" events, this GV is met in several examined water bodies in Vojvodina. For comparison, in two row water supplies of Finnish waterworks microcystins were detected sporadically and the highest microcystin 

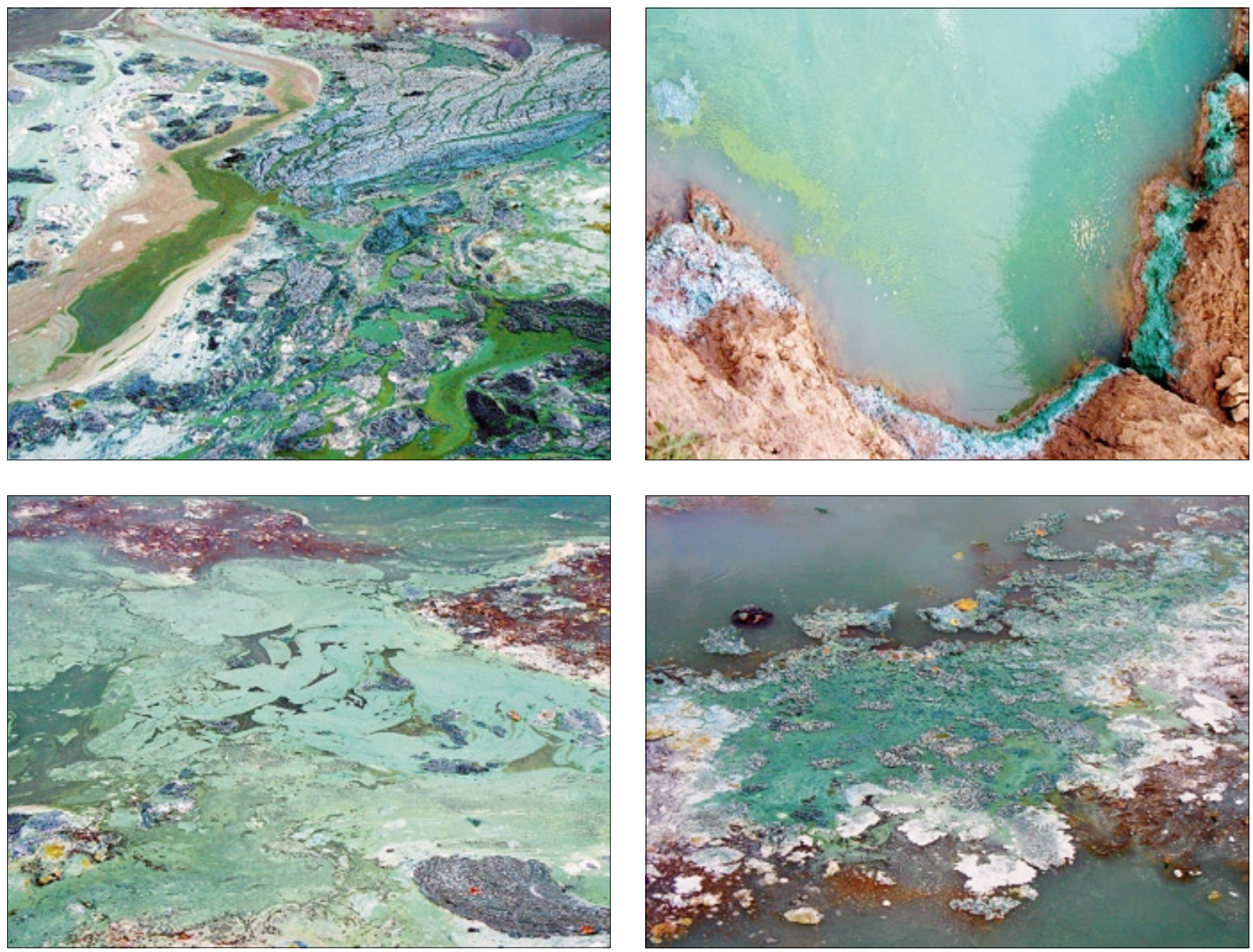

Plate 1 Cyanobacterial "blooming" in Ćelije reservoir in July 2004

concentrations mesaured were approximately $10 \mu \mathrm{gL}^{-1} \mathrm{MC}$-LR equivalents. Microcystin were detected in $40 \%$ of row water samples but usually the concentrations were less than $1 \mu \mathrm{gL}^{-1}$ (Lahti et al., 2001). The results of concentration of microcystin in Portugal indicate that during the most of the sampling period (1999) cyanotoxin values were below $50 \mathrm{ngL}^{-1}$ and the highest concentration was $173 \mathrm{ngL}^{-1}$ (Caetano et al., 2001). The highest recorded and reported microcistyn concentrations in samples with or without detected "blooms" are: $25.000 \mu \mathrm{gL}^{-1}$ and $3.300 \mu \mathrm{gL}^{-1}$ for anatoxin$\mathrm{a}(\mathrm{S})$ in Germany (Chorus et al., 1998); in Japan for 1996 reported microcystin concentrations is $1.300 \mu \mathrm{gL}^{-1}$ (Ueno et al., 1996), while in 1997 as high as 15.600 and 19.500 $\mu \mathrm{gL}^{-1}$ (Nagata et al., 1997).

There is no regular monitoring of the presence of potentially toxic, toxic cyanobacteria and cyanotoxins in drinking and surface waters in Serbia. Specific regulations and legislation on maximum permitted levels of cyanotoxins in water do not exist. The World Health Organisation (WHO) has addressed health hazards presented by cyanotoxins as a part of the WHO Guidelines for Drinking Water Quality. WHO Guideline Value (GV) for total microcystin-LR in drinking water is $1 \mu \mathrm{gL}^{-1}$ (WHO, 1998; WHO 1999; Chorus and Bartram, 1999), limit that is already being used in some countries (e.g. Australia, UK) (Codd, 200o).

Regions in Central Serbia mostly have surface drinking water supply reservoirs that are "blooming" during summer months, compared to Vojvodina that has undergound water supply systems. Consequently, the differences in drinking water quality in this regions might be a result of the presence of hepatotoxins as a product of many "blooming" cyanobacteria.

\section{Conclusions}

More than 80 water ecosystems (lakes, rivers, reservoirs) in Serbia have been monitored for "water blooms" in the last 25 years. In this period, "blooms" have been observed in 58 of them, representing $70 \%$ of the total number, while all 36 monitored ecosystems in Vojvodina region have been "blooming" in different seasons.

During 2005 and 2006 the presence of microcystin-LR in water samples was screened with peak values in the autumn 2005 and spring 2006 at location Ludoš Lake. The concentration of microcystinLR in the water samples were in the range of $1.25-362.68 \mu \mathrm{gL}^{-1}$. The highest concentration of microcystin-LR detected at location Ludoš Lake was $362.68 \mu \mathrm{gL}^{-1}$ in autumn 2005.

"Blooming" of potentially toxic cyanobacteria has also been recorded in reservoirs for water supply. In July 2004, Ćelije reservoir, used as drinking water supply for city of Kruševac and its surroundings, was found "blooming" with taxa belonging to Aphanizomenon, Anabaena and Microcystis. This mass development of toxic cyanobacteria resulted in concentration of microcystin LR $650 \mu \mathrm{gL}^{-1}$ in water of the reservoir, while in the drinking (tap) water of Kruševac city the concentration was $2.5 \mu \mathrm{gL}^{-1}$.

\section{Acknowledgements}

Authors would like to acknowledge the funding of the Ministry of Science and Environmental protection of the Serbian Government (project number: 146021B).

\section{References}

An, J., Carmichael, W.W. 1994. Use of a colorimetric protein phosphatase inhibition assay and enzyme linked immunosorbent assay for the study of microcystins and nodularins. Toxicon 32, 1495-1507. 
Bartram J., Carmichael W.W., Chorus I., Jones G., Skulberg O., 1999. Toxic Cyanobacterial in Water: A guide to their public health consequences monitoring and management, WHO, Chapter 1.

Blaženčić, J., Jovanović, Đ., Cvijan, M., 1990. Oscillatoria rubescens (D.M) biomass in "Uvac" resevoir-causes and consequences. Zbornik radova konferencije "Zaštita voda '9o", 76-80.

Branković, D. 1992. Phytoplankton and saprobiological analysis of the "Palić" Lake. Zbornik radova konferencije “Zaštita voda '92", 75-79.

Branković, D., Budakov, Lj., Sekulić, N. 1998. Phytoplankton as indicator of saprobiological characteristics of some lentic ecosystems. Zaštita prirode 50, 291-296.

Caetano S. Miguel, R. Mendes, P. Galvao, Barbosa A. 2001. Cyanobacterial blooms and cyanotoxin occurrence in the Guadiana (SE-Portugal) - Preliminary results. Ecotoxicology and Environmental Restoration 4, 53-59.

Carmichael, W.W., Azevedo, S.M., An, J.S., Molica, R.J., Jochimsen, E.M., Lau, S., Rinehart, K.L., Shaw, G.R., Eaglesham, G. K. 2001. Human fatalities from cyanobacteria: chemical and biological evidence for cyanotoxins. Environmental Health Perspectives 109, 663-668.

Chorus, I., Bartram J. 1999. Toxic cyanobacteria in water. A guide to their public health consequences, monitoring and management. E\&FN SPON, WHO, England, 1-40o.

Chorus, I., Fastner, J. 2001. Recreational exposure to cyanotoxins, in Cyanotoxins - occurrence, causes, consequences. In: I. Chorus, Editor. Springer-Verlag: Berlin, 190-199.

Codd G. A. 1995. Cyanobacterial toxins: occurrence, properties and biological significance. Water Science Technology 32,149-156.

Codd, G.A. 2000. Cyanobacterial toxins, the perception of water quality, and the prioritisation of eutrofication control. Ecological Engineering 16, 51-60.

Čomić, Lj., Ranković, B. 1991. Changes in bacteria population and phytoplankton and their relations in accumulative lake Gruža. IXth Symposium phycological section, Polish Botanical Association, Poznan, 1990, Part II, 129-140.

Cousins, I.T., Healing, D.J., James, H.A., Sutton, A. 1996 Biodegradation of microcystin-LR by indigenous mixed bacterial populations. Water Research 30, 481-485.

Čađo, S., Đurković, A., Miletić, A., Maljević, E. 2003. Analysis of phytoplankton and trophy state of "Sjenica" reservoir. Zbornik radova konferencije "Ekokonferencija", 117-123.
Čađo, S., Miletić, A., Djurković, A. 2004a. Phytoplankton, physic-chemical characteristics, trophy and saprobity of "Bovan" reservoir. Zbornik radova konferencije "Zaštita voda '04", 25-29.

Čađo, S., Đurković, A., Miletić, A., Andrejević, S., Maljević E. 2004b. Results on phytoplankton analysis and trophy state of "Krajkovac" reservoir. Zbornik radova konferencije "Zaštita voda '04", 217-222.

DeVries, S.E., Galey, F.D., Namikoshi, M., Woo, J.C. 1993. Clinical and pathologic findings of blue-green algae (Microcystis aeruginosa) intoxication in a dog. Journal of Veterinary Diagnostic Investigation 5, 403-408.

Ding, W.X., Shen, H.M., Zhu, H.G., Lee, B.L., Ong, C.N. 1999. Genotoxicity of microcystic cyanobacteria extract of a water source in China. Mutation Research. 442, 69-77.

Dow, C., Swoboda, U. 200o. Cyanotoxins. In: Whitton, B.A. and Potts M. (eds): The ecology of cyanobacteria-their diversity in time and space. Kluwer Academic Publishers, The Netherlands, p. 616.

Dulić, S., Mrkić, B., 1998. Saprobiological investigations of the water quality on basis of the plankton community in Tisa-Palić system. Zbornik radova konferencije "Zaštita voda '98”, 387-392.

Dulić, S., Mrkić, B. 1999. Water quality determination of Lake Ludaš based on plankton communities. Zbornik radova konferencije "Zaštita voda '99", 165170.

Dulić, S., Mrkić, B. 2001. Percentual composition of phytoplankton divisions in tourist part of Lake Palić. Zbornik radova konferencije "Zaštita voda 'o1", 253256.

Đukić, N., Pujin, V., Maletin, S., Gajin, S., Gantar, M., Petrović, O., Ratajac, R., Seleši, Đ., Matavulj, M. 1991a. Lentic waters eutrophication in Vojvodina Part I "Borkovac". Zbornik radova Instituta za biologiju 31, 4-6.

Đukić, N., Pujin, V., Maletin, S., Gajin, S., Gantar, M., Petrović, O., Ratajac, R., Seleši, Đ., Matavulj, M. 1991b. Lentic waters eutrophication in Vojvodina - Part I “Zobnarica”. Zbornik radova Instituta za biologiju 31, 39-40.

Đukić, N., Pujin, V., Maletin, S., Gajin, S., Gantar, M., Petrović, O., Ratajac, R., Seleši, Đ., Matavulj, M., 1991c. Lentic waters eutrophication in Vojvodina - Part I "Palić". Zbornik radova Instituta za biologiju 31,, 52-57.

Đukić, N., Pujin, V., Maletin, S., Gajin, S., Gantar, M., Petrović, O., Ratajac, R., Seleši, Đ., Matavulj, M. 1991d. Lentic waters eutrophication in Vojvodina - Part I "Ludoš". Zbornik radova Instituta za biologiju 31, 73-75.
Đukić, D., Mandić, L., Marković, G., 1994 The influence of cities' Čačak and Gornji Milanovac waste waters on microbial phytoplankton communities in River Zapadna Morava. J. Monte Negro ASA: 239-245.

Đurković, A., Čađo, S., Miletić, A., Bugarski, R., Andrejević, S., Maljević, E. 2004. Results of the water quality investigations based on saprobiological and physic-chemical charactersitics of River Krivaja in 2001 and 2002. Zbornik radova konferencije "Zaštita voda '04", 315-320.

Falconer, I.R. 1999. An overview of problems caused by toxic blue green algae (cyanobacteria) in drinking and recreational water. Environmental Toxicology 14, 5-12.

Falconer, I.R., Burch, M., Steffensen, D., Choice, M., Coverdale, O. 1994. Toxicity of blue green alga (cyanobacterium) Microcystis aeruginosa in drinking water to growing pigs, as an animal model to human injury and risk assessment. Journal of Environmental Toxicology and Water Quality 9, 131-139.

Falconer, I., Bartram, J., Chorus, I., KuiperGoodman, T., Utkilen, H., Codd, G. 1999. Safe levels and practices. In: Chorus I., Bartram J. (eds): Toxic cyanobacteria in water: a guide to their public health consequences, monitoring and management. E\&FN Spon on Behalf of WHO, London, 155-178.

Fastner J., Flieger I. and Neumann U. 1998. Optimised extraction of microcystins from field samples - a comparison of different solvents and procedures. $\mathrm{Wa}$ ter Research 32, 3177-3181.

Fawell, J., Mitchell, R., Everett, D., Hill, R. 1999. The toxicity of cyanobacterial toxins in the mouse: I Microcystin-LR. Human and Experimental Toxicology 18 , 162-167.

Fitzgerald, J.D., 2001. Cyanotoxins and human health - overview. In: Chorus I.(ed): Cyanotoxins-occurrence, causes, consequences. Springer-Verlag, Berlin, Heidelberg, 179-19o.

Gobler, C.J., Davis, T.W., Coyne, K.J., Boyer, G.L. 2007. Interactive influence of nutrient loading, zooplankton grazing and microcystin synthetase gene expression on cyanobacterial bloom dynamics in a eutrophic New York lake. Harmful Algae 6, 119-133.

Grašić, S., Vasiljević, B., Marković, B., Nikolić, G., Tadić, S., Jovanović, B. 2004. Cyanobacterial "blooming" in Ćelije reservoir. Zbornik radova konferencije "Zaštita voda '04", 207-212.

Hanazato, T. 1996. Toxic cyanobacteria and the zooplankton community. In M. F. Watanabe, K.-I. Harada, W. W. Carmichael \& H. Fujiki (eds.) Toxic Micro- 
cystis, CRC Press, Boca Raton, Florida, USA, 79-102.

Harada, K., Oshikata, M., Uchida, H., Suzuki, M., Kondo, F., Sato, K., Ueno, Y., Yu, S.Z., Chen, G., Chen, G.C., 1996. Detection and identification of microcystins in the drinking water of Haimen City, China. Natural Toxins 4, 277-83.

Heinze, R. 1999. Toxicity of the cyanobacterial toxin microcystin-LR to rats after 28 days intake with the drinking water. Environmental Toxicology 14, 57-60.

Hense, I., Beckmann, A. 2006. Towards a model of cyanobacteria life cycle-effects of growing and resting stages on bloom formation of $\mathrm{N}_{2}$-fixing species. Ecological Modeling 195, 205-218.

Hoeger, S., Dietrich, D., Hitzfeld, B. 2002. Effect of ozonation on the removal of cyanobacterial toxins during drinking water treatment. Environmetal Health Perspectives 110, 1127-1132.

Huber, A.L., Hamel, K.S. 1985. Phosphatase activities in relation to phosphorus nutrition in Nodularia spumigena (Cyanobacteriaceae). Hydrobiologia $123,145-152$

IARC, Ingested nitrate and nitrite, and cyanobacterial peptide toxins. International Agency for Research on Cancer IARC monographs on the evaluation of carcinogenic risks to humans. Volumen 94 (in press).

Kahru, M., Horstmann, U., Rud, O. 1994. Satellite detection of increased cyanobacteria blooms in the Baltic Sea: natural fluctuation or ecosystem change? Ambio 23, 469-472.

Kahru, M., Lepp“anen, J.M., Rud, O., Savchuk, O.P. 200o. Cyanobacteria blooms in the Gulf of Finland triggered by saltwater inflow into the Baltic Sea. Marine Ecolology Progress Series 207, 13-18.

Kalafatić, V., Obušković, Lj., Živković, A. 1982. A contribution to phytoplankton studies of some waters in North Banat. Archiv of Biological Sciences 34, 89-101.

Karadžić, V., Subakov-Simić, G. 2002. High production of phytoplankton in the Ponjavica river (South Banat) in the winter period. IAD Research 34, 153-161.

Karadžić, V., Subakov-Simić, G., Cvijan, M. 2005. Blue green algae (Cyanophyta) of River Ponjavice. Zbornik radova konferencije "Zaštita voda '05", 183-188.

Karadžić, V., Subakov-Simić, G., Natić, D. 2006. Phytoplankton analisys of the reservoirs Garaši and Bukulja near Aranđelovac city. Proceedings of the II International Symposium of ecologists of the Republic of Montenegro, 117-123.

Lahti, K., Rapala, J., Kivimäki, A.-L., Kukkonen, J., Niemelä, M., Sivonen, K. 2001. Occurrence of microcystins in raw water sources and treated drinking water of Finnish waterworks. Water Science and Technology 43, 225-228.
Laušević, R., Nikitović, J., Tomašević, V. 1998. Phytoplankton in river Sava near Belgrade. Ekologija 33, 29-40.

Marković, S.B., Svirčev Z. (eds) 1998. Our Tamiš - A Scientific Monography. Institute of Geography, Novi Sad, pp 43-57.

Martinović-Vitanović, V., Kalafatić, V. 1990. Classification of some reservoirs in SR Serbia (SFR Yugoslavia) based on analysis of plankton species as indicators of trophic conditions. Archiv Hydrobiologie 33, 831-837.

Martinović-Vitanović, V., Kalafatić V. 1996. Biological aspects. In: Drinking water quality-recommended standards and proceedures. State departement for Health Protection, Belgrade, 79-87.

Maslać, M., Obušković, Lj., Jakovčev, D., Cakić, P., Tucović, V. 1992. Previous investigations of Opovo channel, one in the system of channels of Pančevo, 2833.

Matsunaga, H., Harada, K.I., Senma, M., Ito, Y., Yasuda, N., Ushida, S., Kimura, Y. 1999. Possible cause of unnatural mass death of wild birds in a pond in Nishinomiya, Japan: sudden appearance of toxic cyanobacteria. Natural Toxins 7, 81-84.

Miljković, D., Vučković, M., Gotović, D., Milenković, P., Žarkov, N., Raški, Đ. 2004. Water supply problems of $\mathrm{Ma}$ jdanpek. Zbornik radova konferencije "Zaštita voda '04", 575-579.

Milovanović, D. 1963. Phytoplankton and primary production in fish ponds "Koluta". Archive Biological Sciences 6, 3-16.

Milovanović, D. 1970. Limno-typological changes of some waters as a consequence of meliorative works in River Dunav hidrosystem near Apatin. Ekologija 5, 55-70.

Milovanović, D. 1973. Phytoplankton structural chnages in the first years of Đerdap reservoir existence. Archive Biological Sciences 25, 75-83.

Milovanović, D., Živković, A. 1953. Plankton production investigations in Ečka fish ponds. Proceedings S.A.N. XXIX (3), 197-264.

Milovanović, D., Živković, A. 1959. Phytoplankton production in Živača fish pond (II Contribution to limnololgy of lentic waters in Panonia valley). Archive Biological Sciences 2, 1-17.

Milovanović, D., Živković, A. 1963. Phytoplankton composition and dynamics in Jegrička fish pond in1959-1960 period. Archive Biological Sciences 6, 3-30.

Mulholland, M.R., Floge, S., Carpenter, E.J., Carpone, D.G. 2002., Phosphorus dynamics in cultures and natural populations of Trichodesmium spp. Mar. Ecol. Prog. Ser. 239: 45-55.

Nagata, S., Tsutsumi, T., Hasegawa, A., Yoshida, F., Ueno, Y. and Watanabe, M.F. 1997 Enzyme immunoassay for di- rect determination of microcystins in environmental water. J. AOAC Int., 8o, 408-417.

Obušković, Lj. 1982a. Dynamics of phytoplankton and some ecological factors as a consequence of eutrophication in Lake Sava near Belgrade. Vodoprivreda 14, 75-76.

Obušković, Lj. 1982b. Phytoplankton and saprobiological characteristics of rivers Bosut, Spačva and Studva. Vodoprivreda 14, 247-249.

Obušković, Lj. 1983. Das Phytoplankton des Stausees „Eisernes Tor" (Đerdap) im Jahre 1973. Hidrobiologia 17, 341-347.

Obušković, Lj. 1986. Phytoplankton and water quality of several reservoirs in SR Serbia. Fitoplankton i kvalitet vode nekoliko hidroakumulacija u SR Srbiji. Zbornik radova konferencije "Zaštita voda ' 86 ', 152-156.

Obušković, Lj. 1987. Phytoplankton and saprobiological characteristics of River Sava in 1984. Proceedings of Conference "River Sava, protectioin and water use", Zagreb, 426-430.

Obušković, Lj., 1989. Phytoplankton and saprobiological characteristics of River Danube in 1988. Zbornik radova konferencije "Zaštita voda '89", 30-36.

Obušković, Lj., 1991. Phytoplankton and saprobiological charactersitics of River Ponjavice (South Banat) as indicator of increased eutrophication. Zbornik radova konferencije "Zaštita voda '91", 332-337.

Obušković, Lj., Kalafatić, V. 1988. Biological, saprobiological and physic-chemical characteristics of River Pek and its tributaries Zbornik radova konferencije "Zaštita voda '88”, 240-253.

Oliver, R., Ganf, G. 200o. Freshwater blooms. In: Whitton, B.A. and Potts M. (eds) The ecology of cyanobacteriatheir diversity in time and space. Kluwer Academic Publishers, The Netherlands, p.166.

Peršić, M., 1997. Eutrophication and drinking water treatement. Special Edition Geoinstitute 22, 34-52.

Pujin, V., Ratajac, R. 1990. Zooplankton formations in Međeš reservoir. Zbornik radova konferencije "Zaštita voda '9o", 109-113.

Pujin, V., Ratajac, R., Đukić, N., Svirčev, Z., Kilibarda, P. 1987. Saisonmassige variationen der zusammemensetzung des planktons und der bodenbesiedlung in der Carska bara (Jugoslawien). Tiscia (Szeged) XXII, 83-91.

Pujin, V., Ratajac, R., Svirčev, Z., Kilibarda, P. 1986. Phytoplankton composition and dynamics in some OKM channels of DTD hydrosystem as basis for fish production. Zbornik radova konferencije "Zaštita voda ' 86 ", 279-284. 
Pujin, V., Stojković, S., Đukić, N., Miljanović, B., Maletin, S., Sekulić, A., Teodorović, I. 1999. Hydrobionts-water quality indicators of River Tisa. Zbornik radova konferencije "Zaštita voda '99", 239-242.

Puschner, B., Galey F.D., Johnson B., Dickie C.W., Vondy M., Francis T., Holstege D.M. 1998. Blue-green algae toxicosis in cattle. Journal of American Veterinary Medical Association 213, 1605-7, 1571.

Ranković, B., Čomić, Lj., Simić S. 1994. Phytoplankton and saprobiological characteristics of Gruža reservoir in 1992. Zbornik radova konferencije "Zaštita voda '94", 110-115.

Ranković B., Čomić Lj. 1989. Phytoplankton studies of Gruža reservoir. Zbornik radova konferencije "Zaštita voda ' 89 ", 397-403.

Ranković, B., Simić, S. 2005. Phytoplankton of Gruža reservoir. In: Gruža Reservoir - Monography. Faculty of Natural Sciences, Kragujevac, 65-78.

Ristić, O., Gajin, S., Gantar, M., Matavulj, M. 1979. Microbiological studies of some fish ponds in Vojvodina. Proceedings of the II Congress of Ecologists in Yugoslavia, Zagreb, 1923-1935.

Seleši, Đ. 1981. Limnological investigations of Lake Ludoš. Vode Vojvodine 9, 333352.
Seleši, Đ. 1982. Limnological investigations of Lake Palić. Vode Vojvodine 10, 345-368.

Sellner, K.G., Doucette, G.J., Kirkpatrick, G.J. 2003. Harmful algal blooms: causes, impacts and detection. Journal of Indistrial Microbiology and Biotechnology 30, 383-406.

Simeunović J., Svirčev Z., Krstić S., Lazić L. 2005. Occurance of cyanobacterial blooms in Vojvodina water ecosystems. Geographica Pannonica 9, 13-19.

Subakov-Simić, G., Plemić, N., Karadžić, V., Cvijan, M., Krizmanić, J., 2004. Qualitative and quantitative analysis of phytoplankton in Slatina near Opovo. Zbornik radova konferencije "Zaštita voda '04", 327-330.

Svirčev, Z. 1983. Summer aspect of microflora and microfauna in some waters of Fruška Gora. Čovek $i$ životna sredina 6 , 38-43.

Svirčev, Z. 2006. Microalgae and cyanobacteria in biotechnology. Faculty of Natural Sciences, Novi Sad, "Alfa94" publications, 1-215.

Takenaka, S., Watanabe, M.F. 1997. Microcystin LR degradation by Pseudomonas aeruginosa alkaline protease. Chemosphere 34, 749-57.

Tsuji, K., Watanuki, T., Kondo, F., Watanabe, M., Suzuki, S., Nakazawa, H., Suzuki, M., Uchida, H., Harada, K.I. 1995. Stability of microcystins from cyano-
bacteria-II. Effect of UV light on decomposition and isomerization. Toxicon 33, 1619-1631.

Ueno Y., Nagatai S., Tsutsumi T., Hasegawa A., Watanabe M, Park H., Chen G. Chen G. and Yu S. 1996. Detection of microcystins, a blue-green algal hepatotoxin, in drinking water sampled in Haimen and Fusui, endemic areas of primary liver cancer in China, by highly sensitive immunoassay. Carcinogenesis 17, 1317-1321.

Urošević, V. 1993. Plankton primary production changes in Gazivode reservoir Glasnik Instituta za botaničke bašte XXIV-XXV, 105-113

Villareal, T.A., Carpenter, E.J. 2003. Buoyancy regulation and the potential for vertical migration in the oceanic cyanobacterium Trichodesmium. Microbial Ecolology 45, 1-10.

Welker, M., Steinberg, C.I. 1999. Indirect photolysis of cyanotoxins: one possible mechanism for their low persistence. Water Research 33, 1159-1164.

WHO, 1998. Cyanobacterial toxins: Microcystin-LR. In: Guidelines for drinkingwater quality, Addendum to Volume 2. Geneva: World Health Organization, Geneva.

WHO, 1999. Toxic cyanobacteria in water: A guide to their public health consequences, monitoring and manegment. Great Britain. 